\title{
Fiber Reinforced Composite Space Maintainers Versus Band and Loop Space Maintainers - A Systematic Review
}

\author{
Vaishnavi Padmanabhan ${ }^{1}$, Shreya Kishore ${ }^{2}$, Suvetha ${ }^{3}$ \\ ${ }^{1}$ SRM Dental College, Ramapuram, Chennai, Tamil Nadu, India, 2, 3 Department \\ Orthodontics, SRM Dental College, Ramapuram, Chennai, Tamil Nadu, India.
}

\section{ABSTRACT}

\section{BACKGROUND}

Premature loss of primary teeth requires orthodontic intervention to prevent the occurrence of malocclusions in the future. The most preferred way to maintain this space is by using space maintainers. Band and loop maintainers are the most commonly used fixed space maintainers. Despite being the most effective, it has several disadvantages. Hence, the objective of this review was to compare the efficiency between fiber reinforced composite (FRC) space maintainer and the conventional band \& loop space maintainer.

\section{METHODS}

A systematic review was performed. Electronic and hand search retrieved 260 records, 246 were screened. The intervention and outcomes were assessed in the study included for systematic review.

\section{RESULTS}

Seven studies were included in this systematic review. These studies compared the fiber reinforced composite and the conventional band \& loop and provided results about their clinical efficacy and patient satisfaction.

\section{CONCLUSIONS}

Despite being one of the gold standard appliances for space maintenance, the conventional band and loop space maintainers have multiple disadvantages. The major disadvantages included failure of the appliance due to cement loss and bending of the wire. Out of the 7 articles included in this study, 6 of the articles concluded that the FRC space maintainers are as effective as the conventional band and loop. FRC space maintainers proved to be time effective, more aesthetic, has better patient acceptance and is easier to fabricate. Hence, fiber reinforced composite space maintainers can be used as a more aesthetic and effective alternative to the conventional band and loop space maintainers if proper technique and protocol is followed.

\section{KEY WORDS}

Space Maintainers, Band and Loop Space Maintainer, Fiber Reinforced Space Maintainer, Interceptive Orthodontics, Orthodontics
Corresponding Author: Dr. Shreya Kishore, Senior Lecturer, Department of Orthodontics, SRM Dental College, Barathi Salai, Ramapuram, Chennai - 600089,

Tamil Nadu, India.

E-mail:dr.shreyakishore@gmail.com

DOI: $10.14260 / \mathrm{jemds} / 2021 / 512$

How to Cite This Article:

Padmanabhan V, Kishore S, Suvetha S. Fiber reinforced composite space maintainers versus band and loop space maintainers - a systematic review. J Evolution Med Dent Sci 2021;10(31):2505-2510, $10.14260 /$ jemds $/ 2021 / 512$

Submission 04-05-2021, Peer Review 07-07-2021, Acceptance 13-07-2021, Published 02-08-2021.

Copyright (C) 2021 Vaishnavi Padmanabhan et al. This is an open access article distributed under Creative Commons Attribution License [Attribution 4.0 International (CC BY 4.0)] 


\section{BACKGROUND}

Primary dentition is highly integral in the growth and development of a child. It not only aids in functions such as mastication and speech but also act as natural space maintainers to guide the eruption of the permanent teeth. ${ }^{1}$ One of the most common cause of malocclusions is tooth material arch length discrepancy which usually occurs due to premature loss of primary teeth. ${ }^{2}$ Premature loss of primary teeth either due to dental caries or trauma leads to multiple issues such as drifting of adjacent teeth towards the space, supra eruption of opposing teeth and shift in midline. This poses difficulty for the erupting permanent teeth due to insufficient space for eruption and loss of arch length. ${ }^{3}$ Hence, a method of intervention is necessary to prevent malocclusion from occurring in the permanent dentition.

Space maintainers can be defined as a fixed or removable appliance placed to maintain space created by the premature loss of a tooth or teeth. They are the most preferred orthodontic appliance to preserve the space and guide the permanent tooth into the proper position in the dental arch. As maximum space loss occurs within 6 months after the loss of primary teeth, it is indicated to place the space maintainer immediately after the loss of tooth. ${ }^{4}$ Space maintainers can be classified based on various criteria such as fixed/removable or functional/non-functional or banded/bonded. ${ }^{1}$ Most rendered space maintainers are either removable or fixed. Removable maintainers are easier to clean and aid in good oral hygiene maintenance, but it requires good amount of patient cooperation in order to be effective. Whereas the fixed maintainer requires less parent and patient compliance and is comparatively easier to maintain. ${ }^{3}$

Among the fixed space maintainers, band and loop maintainer is the most commonly used variant in case of unilateral single tooth loss. Despite being the most preferred appliance, it has various disadvantages such as need for multiple visits, dislodgement due to loss of cement, fracturing and bending of loop due to occlusal forces, decalcification under the bands and the promotion of occurrence of caries in the abutment tooth. ${ }^{3,4}$ They also don't prevent the rotation and tipping the abutment tooth. To overcome the shortcomings of the band and loop space maintainer, newer variants such as fiber reinforced composite space maintainers have been developed. These space maintainers contain composite resin impregnated with polyethylene fibers or glass fibers. These fibers drastically improve the mechanical properties of the composite such as stiffness, strength, and fracture toughness. These fibers supposedly bear the stress and prevent crack formation by either deflecting or stopping the crack propagation. ${ }^{5}$ Not a lot of literature is present about the fiber reinforced composite space maintainer.

Hence, this systematic review aims at comparing the band and loop and fiber reinforced space maintainer and determine which is more efficient.

\section{METHODS}

A systematic computerized search was performed on electronic databases such as PubMed, Medline, Cochrane, google scholar, Wiley online library and manual searches were conducted in journals like American journal of orthodontics and dentofacial orthopaedics (AJODO), Journal of orthodontics (JO), Journal of clinical orthodontics (JCO) and seminar in orthodontics.

\section{Search Words}

Specific keywords were used for each electronic database, such as in PubMed (Advanced search) the search word used was ((( (fiber reinforced composite) or (space maintainer)) or (fiber reinforced space maintainer)) and (band and loop space maintainer)) or (fixed space maintainer). Other search words can be found in Table 1 .

\begin{tabular}{|c|c|c|c|}
\hline Sl. No. & Database & Search Terms & $\begin{array}{l}\text { Articles } \\
\text { Found }\end{array}$ \\
\hline 1 & $\begin{array}{l}\text { PubMed central } \\
\text { (Advanced } \\
\text { search) }\end{array}$ & $\begin{array}{l}\text { ((((fiber reinforced composite) OR (space } \\
\text { maintainer)) OR (fiber reinforced space } \\
\text { maintainer)) AND (band and loop space } \\
\text { maintainer)) OR (fixed space maintainer) }\end{array}$ & 3 \\
\hline 2 & MedLine & $\begin{array}{l}\text { (((fiber reinforced composite) OR (space } \\
\text { maintainer)) OR (fiber reinforced space } \\
\text { maintainer)) AND (band and loop space } \\
\text { maintainer)) OR (fixed space maintainer) }\end{array}$ & 3 \\
\hline 3 & Cochrane & $\begin{array}{l}\text { (fiber reinforced composite) OR (space } \\
\text { maintainer orthodontics) OR (fiber reinforced } \\
\text { space maintainer) AND (band and loop space } \\
\text { maintainer) OR (fixed space maintainer) }\end{array}$ & 67 \\
\hline 4 & Google scholar & $\begin{array}{l}\text { fiber reinforced composite space maintainer } \\
\text { versus fixed band and loop space maintainer }\end{array}$ & 183 \\
\hline 6 & $\begin{array}{l}\text { Wiley online } \\
\text { library }\end{array}$ & $\begin{array}{l}\text { fiber reinforced composite space maintainer } \\
\text { versus fixed band and loop space maintainer }\end{array}$ & 7 \\
\hline 7 & $\begin{array}{l}\text { Complimentary } \\
\text { individual } \\
\text { journal search }\end{array}$ & $\begin{array}{l}\text { fiber reinforced composite space maintainer } \\
\text { versus fixed band and loop space maintainer }\end{array}$ & 0 \\
\hline & & Table 1. Search Database & \\
\hline
\end{tabular}

\section{Inclusion Criteria}

The articles that were included in this review fell under the following criteria:

- Articles comparing fiber reinforced space maintainers and band and loop space maintainers

- Articles published in English were included

- Full text articles were included

- $\quad$ Studies published between 1st January 2010 and 31st December 2020.

\section{Exclusion Criteria}

The articles that were excluded in this review fell under the following criteria:

- Articles published in other languages

- Articles where only abstracts were available

- Articled that were irrelevant

- Review articles

- Case reports

- Editorials

\section{Data Extraction}

A systematic electronic search was conducted on databases and articles were collected. These articles were scrutinized based on the inclusion, exclusion criteria and 7 relevant articles were chosen for this systematic review.

Table 2 contains the prisma flow chart indicating the number of articles obtained and scrutinized. 


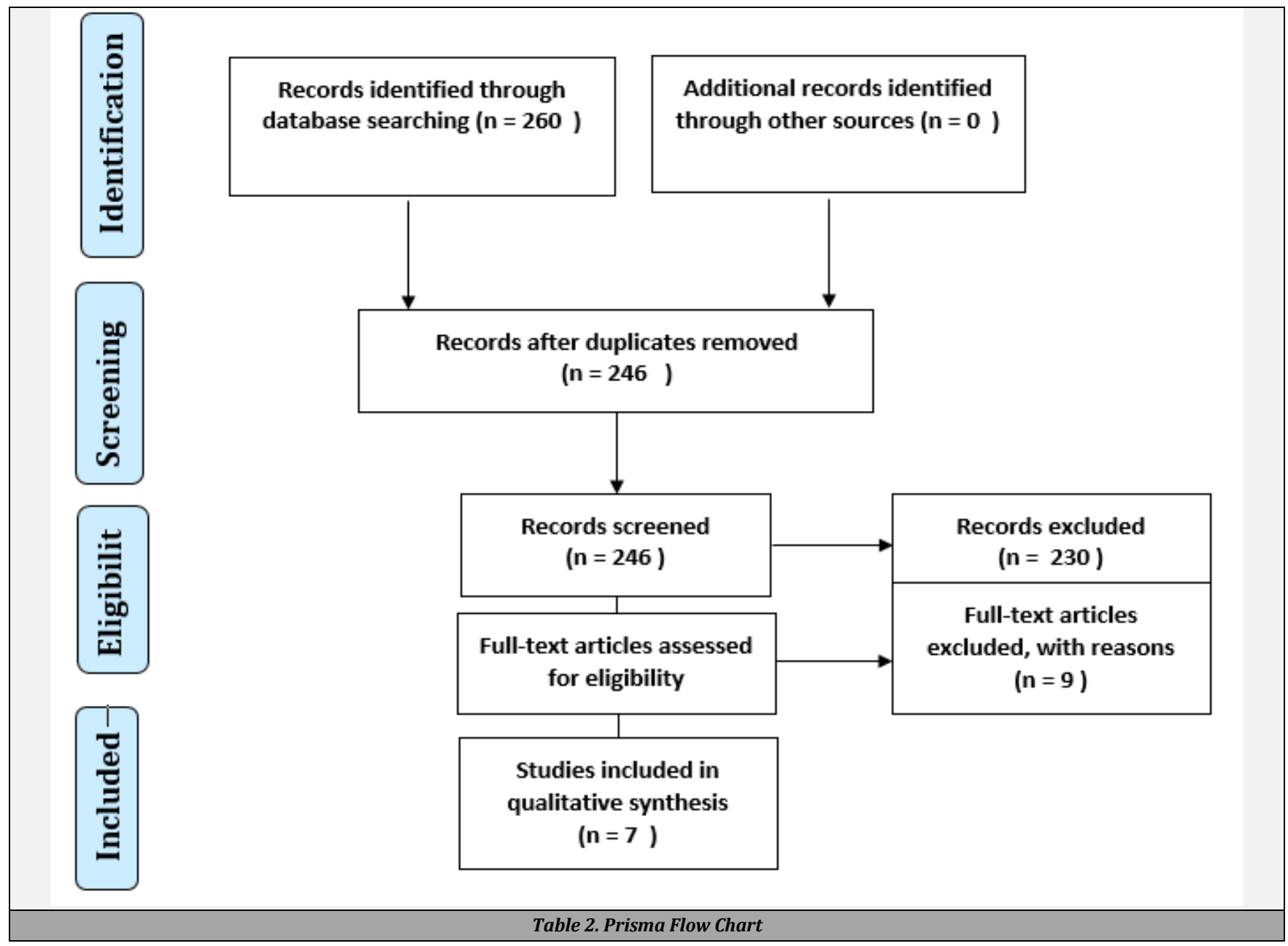

\begin{tabular}{|c|c|c|c|c|c|c|c|}
\hline $\begin{array}{l}\text { Sl. } \\
\text { No }\end{array}$ & $\begin{array}{l}\text { Author, } \\
\text { Year }\end{array}$ & $\begin{array}{l}\text { Type of } \\
\text { Study }\end{array}$ & Sample Group & $\begin{array}{l}\text { Period of } \\
\text { Follow up }\end{array}$ & $\begin{array}{l}\text { Method of Evaluation } \\
\text { and Analysis }\end{array}$ & Result & Conclusion by Author \\
\hline 1 & $\begin{array}{l}\text { Mittal S et } \\
\text { al. } 2018\end{array}$ & $\begin{array}{l}\text { Comparative } \\
\text { study }\end{array}$ & $\begin{array}{l}45 \text { extraction sites; Group } \\
\text { I - Conventional band \& } \\
\text { loop; Group II - Glass } \\
\text { FRCR (ever Stick C and } \\
\text { B); Group III - Glass } \\
\text { impregnate FRCR } \\
\text { (interlig) }\end{array}$ & $\begin{array}{l}3^{\text {rd }}, 6^{\text {th }}, 12^{\text {th }} \text { month } \\
\text { follow up }\end{array}$ & $\begin{array}{l}\text { Patient acceptance by Wong } \\
\text { baker scale Swaine and } \\
\text { wright space measurement } \\
\text { method; Statistical analysis } \\
\text { using chi square test and I } \\
\text { Kruskal-Wallis test }\end{array}$ & $\begin{array}{c}\text { Success rate at } 3 \text { months }-\mathrm{I}= \\
93.4 \% \mathrm{II}=86.7 \% \mathrm{III}=86.7 \\
\% ; 6 \mathrm{months}-\mathrm{I}=86.7 \% \mathrm{II}= \\
80 \% \mathrm{III}=80 \% ; 12 \text { months }- \\
\mathrm{I}=86.7 \% \mathrm{II}=80 \% \mathrm{III}=73.3 \\
\%\end{array}$ & $\begin{array}{l}\text { FRCR has better patient acceptability, cost } \\
\text { effective, time efficient, even if applied on } \\
\text { one side it showed the same efficacy as } \\
\text { applied on } 2 \text { sides, equally efficient as band } \\
\text { and loop clinically }\end{array}$ \\
\hline 2 & $\begin{array}{l}\text { Tunc et al. } \\
2012\end{array}$ & $\begin{array}{l}\text { Comparative } \\
\text { study }\end{array}$ & $\begin{array}{l}30 \text { children (Group } 1=10 \\
\text { band \& loop; Group } 2= \\
10 \text { direct bonded space } \\
\text { maintainer; Group } 3=10 \\
\text { FRC space maintainer) }\end{array}$ & $\begin{array}{l}3^{\text {rd }}, 6^{\text {th }}, 9^{\text {th }}, 12^{\text {th }} \\
\text { month follow up }\end{array}$ & $\begin{array}{l}\text { Cumulative survival rates } \\
\text { measured using Kaplan - } \\
\text { Meier method }\end{array}$ & $\begin{array}{l}\text { Failure rates band \& loop - } \\
10 \% \text {, direct bonded space } \\
\text { maintainer - } 60 \% \text {, FRC } \\
\text { space maintainer - } 80 \%\end{array}$ & $\begin{array}{l}\text { Survival time and success rates of band \& } \\
\text { loop is more than others, Direct bonded } \\
\text { space maintainers have satisfactory } \\
\text { survival time but high failure rate, FRC has } \\
\text { poor survival time and high failure rate. } \\
\text { Failure time and survival rate is unrelated } \\
\text { to patient age, sex or jaw side. }\end{array}$ \\
\hline 3 & $\begin{array}{l}\text { Rani et al. } \\
2019\end{array}$ & $\begin{array}{l}\text { Comparative } \\
\text { study }\end{array}$ & $\begin{array}{l}30 \text { children (FRC in one } \\
\text { quadrant and band } \& \\
\text { loop in one quadrant) }\end{array}$ & $\begin{array}{l}1^{\text {st }}, 3^{\text {rd }}, 6^{\text {th }}, 9^{\text {th }} \text { month } \\
\text { follow up }\end{array}$ & $\begin{array}{l}\text { Statistical analysis using the } \\
\text { ANOVA test and post-hoc } \\
\text { Tukey test }\end{array}$ & $\begin{array}{l}\text { Overall success rate - } 85 \% \\
\text { for FRCR and } 60 \% \text { for B \& L }\end{array}$ & FRCR has shown superior retention rate \\
\hline 4 & $\begin{array}{l}\text { Saravanaku } \\
\text { mar et al. } \\
2013\end{array}$ & $\begin{array}{l}\text { Clinical follow } \\
\text { up study }\end{array}$ & 30 children & $\begin{array}{l}1^{\text {st }}, 6^{\text {th }}, 12^{\text {th }}, 18^{\text {th }} \\
\text { month follow up }\end{array}$ & $\begin{array}{l}\text { Statistical analysis using } \\
\text { fisher exact test and Kaplan } \\
\text { Meiner survival analysis }\end{array}$ & $\begin{array}{l}\text { Mean survival time of FRC is } \\
12 \text { months }\end{array}$ & $\begin{array}{c}\text { FRC can be accepted as successful space } \\
\text { maintainer only for short periods. Success } \\
\text { rate depends on operator experience, } \\
\text { isolation and choosing favourable patient } \\
\text { groups. }\end{array}$ \\
\hline 5 & $\begin{array}{l}\text { Potgieter et } \\
\text { al. } 2018\end{array}$ & In vivo study & $\begin{array}{c}20 \text { patients }(10 \mathrm{FRC} \text { and } \\
10 \mathrm{~B} \& \mathrm{~L})\end{array}$ & $\begin{array}{l}\text { 6-month study } \\
\text { with monthly } \\
\text { follow up }\end{array}$ & $\begin{array}{l}\text { Statistical analysis by two - } \\
\text { sample t-test and the non- } \\
\text { parametric Wilcoxon rank } \\
\text { sum test }\end{array}$ & $\begin{array}{l}\text { Overall failure rate for FRC } \\
50 \% \text { and B \& L } 50 \%\end{array}$ & $\begin{array}{l}\text { Overall failure rate of both don't show } \\
\text { significant differences. } 0.8 \mathrm{~mm} \text { diameter } \\
\text { wire for Band \& Loop is not efficient. } \\
\text { Effectiveness of the loop - design FRC is } \\
\text { limited by bond strength }\end{array}$ \\
\hline 6 & $\begin{array}{l}\text { Garg A et al. } \\
\quad 2014\end{array}$ & $\begin{array}{l}\text { Comparative } \\
\text { study }\end{array}$ & $\begin{array}{l}30 \text { children, Group I = } \\
\text { FRC in one quadrant } \\
\text { Group II = Band and loop } \\
\text { in another quadrant }\end{array}$ & $\begin{array}{l}1^{\text {st }, 3 \text { rd }} \text { and } 6^{\text {th }} \\
\text { month follow up }\end{array}$ & $\begin{array}{l}\text { Patient acceptance by Wong } \\
\text { baker scale; Statistical } \\
\text { analysis using chi square test } \\
\text { and Mann-Whitney U test }\end{array}$ & $\begin{array}{l}\text { Success rate group I }=63.3 \\
\% \text { and group II }=36.7 \%\end{array}$ & $\begin{array}{c}\text { Patient acceptance is better in FRCR. Time } \\
\text { taken for FRCR is lesser, FRCR is superior } \\
\text { in clinical efficacy. } \\
\text { FRCR is an alternative to conventional } \\
\text { band and loop }\end{array}$ \\
\hline 7 & $\begin{array}{l}\text { Yassa et al. } \\
\quad 2017\end{array}$ & $\begin{array}{l}\text { In vitro and in } \\
\text { vivo study }\end{array}$ & $\begin{array}{c}\text { In vitro = (Group 1 = } \\
\text { composite resin without } \\
\text { fibers - } 5 \text { samples; Group } \\
2 \text { = FRC with } 1 \text { fiber } \\
\text { bundle - } 5 \text { samples; } \\
\text { Group } 3 \text { = FRC bars with } \\
2 \text { fiber bundles - } 5 \\
\text { samples) In vivo = } 15 \\
\text { children (FRC in one side } \\
\text { and B \& L in other side) } \\
\end{array}$ & $\begin{array}{c}\text { In vivo }= \\
1^{\text {st, }}, 3^{\text {rd }}, 6^{\text {th }}, 12^{\text {th }} \\
\text { month follow up }\end{array}$ & $\begin{array}{c}\text { In vitro evaluation mean } \\
\text { flexural strength measured } \\
\text { by } 3 \text { point bend test, In vivo } \\
\text { study = } 5 \text { point Likert scale } \\
\text { for patient and parent } \\
\text { satisfaction and gingival } \\
\text { health by Loe and Silness } \\
\text { index }\end{array}$ & $\begin{array}{l}\text { In vitro }- \text { mean structural } \\
\text { strength of group } 1=97.817 \\
\pm 6.003, \text { group } 2=132.234 \pm \\
11.354, \text { group } 3=184.089 \pm \\
9.130 \text { In vivo }=\text { FRC success } \\
\text { rate }=93.3 \% \text { band \& loop } \\
\text { success rate }=86.7 \%\end{array}$ & $\begin{array}{c}\text { Author suggested use of } 2 \text { glass fiber } \\
\text { bundle to reinforce composite for space } \\
\text { maintainer for primary molar. FRC is } \\
\text { superior alternative to B \& L. Further } \\
\text { studies required to develop the best design } \\
\text { of FRC SM }\end{array}$ \\
\hline \multicolumn{8}{|c|}{ Table 3. Data Collection and Analysis } \\
\hline
\end{tabular}




\section{RESULTS}

The search yielded 260 articles, out of which, 246 were screened and were assessed independently. Among these articles, 7 articles were included and studied for this systematic analysis. (Table 3) A bias chart was also prepared for the 7 chosen articles, to check their authenticity. (Table 4)

\begin{tabular}{|c|c|c|c|c|c|c|c|}
\hline 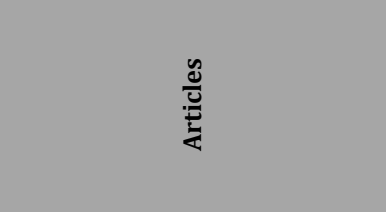 & 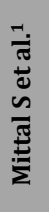 & 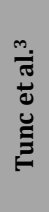 & 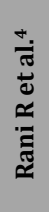 & 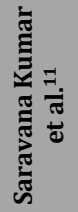 & 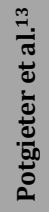 & 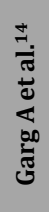 & 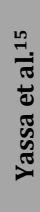 \\
\hline Sample size calculation & $\checkmark$ & $\checkmark$ & $\checkmark$ & $\checkmark$ & $\checkmark$ & $\checkmark$ & $\checkmark$ \\
\hline $\begin{array}{l}\text { Representativeness of orthodontic } \\
\text { patients }\end{array}$ & $\checkmark$ & $\checkmark$ & $\checkmark$ & $\checkmark$ & $\checkmark$ & $\checkmark$ & $\checkmark$ \\
\hline $\begin{array}{l}\text { Selection of the orthodontic control } \\
\text { group }\end{array}$ & $\checkmark$ & $\checkmark$ & $\checkmark$ & $x$ & $\checkmark$ & $\checkmark$ & $\checkmark$ \\
\hline Assessment of space maintenance & $\checkmark$ & $\checkmark$ & $\checkmark$ & $\checkmark$ & $\checkmark$ & $\checkmark$ & $\checkmark$ \\
\hline $\begin{array}{c}\text { Outcome of interest not present at the } \\
\text { start }\end{array}$ & $\checkmark$ & $\checkmark$ & $\checkmark$ & $\checkmark$ & $\checkmark$ & $\checkmark$ & $\checkmark$ \\
\hline Assessors qualified to provide results & $\checkmark$ & $\checkmark$ & $\checkmark$ & $\checkmark$ & $\checkmark$ & $\checkmark$ & $\checkmark$ \\
\hline $\begin{array}{c}\text { Description of inclusion/exclusion } \\
\text { criteria }\end{array}$ & $\checkmark$ & $\checkmark$ & $\checkmark$ & $\checkmark$ & $\checkmark$ & $\checkmark$ & $x$ \\
\hline $\begin{array}{l}\text { Comparability of groups on the basis of } \\
\text { the design }\end{array}$ & $\checkmark$ & $\checkmark$ & $\checkmark$ & $x$ & $\checkmark$ & $\checkmark$ & $\checkmark$ \\
\hline $\begin{array}{l}\text { Assessment of factors that could } \\
\text { influence outcome }\end{array}$ & $\checkmark$ & $\checkmark$ & $\checkmark$ & $\checkmark$ & $\checkmark$ & $\checkmark$ & $\checkmark$ \\
\hline Is the technique of assessment correct & $\checkmark$ & $\checkmark$ & $\checkmark$ & $\checkmark$ & $\checkmark$ & $\checkmark$ & $\checkmark$ \\
\hline Adequacy of follow-up of patients & $\checkmark$ & $\checkmark$ & $\checkmark$ & $\checkmark$ & $\checkmark$ & $\checkmark$ & $\checkmark$ \\
\hline Validity of statistical analysis & $\checkmark$ & $\checkmark$ & $\checkmark$ & $\checkmark$ & $\checkmark$ & $\checkmark$ & $\checkmark$ \\
\hline \multicolumn{8}{|c|}{ Table 4. Bias Table Chart } \\
\hline
\end{tabular}

\section{DISCUSSION}

Numerous events occur as the occlusion develops from the primary dentition through the mixed dentition into the permanent dentition. The events are integral in the development of a functional, aesthetic, and stable occlusion. If this sequence is disrupted, it will eventually affect the final occlusion in the permanent dentition. ${ }^{6}$ Primary teeth basically act as natural space maintainers for the permanent dentition. This is an additional function apart from its primary aid in speech, chewing, appearance and prevention of bad oral habits. The exfoliation of these teeth is a physiological process although if there is premature loss of these teeth, multiple malocclusions such as crowding, impaction of the succedaneous tooth are prone to occur. ${ }^{7}$ It also causes numerous issues like loss of arch length, shift in midline, tilting of adjacent teeth into the edentulous space and supra eruption of opposing tooth. ${ }^{3}$

Hence, maintenance of this space may eliminate or reduce these consequences. ${ }^{8}$ Space maintainers are orthodontic appliances which help preserve the space caused by premature loss of tooth. It is one of the safest approaches to maintain the arch length. ${ }^{1}$ Space maintainers preserves this space and also helps guide the erupting tooth into its right position in the dental arch thus minimizing the need for orthodontic correction in the future. ${ }^{4}$ Various appliance can be given to the child based on their age, growth, stage of dental development, arch involved, location of the missing tooth and patient's ability to co-operate.6,8

Space maintainers can be broadly classified into fixed and removable. The most commonly used fixed space maintainer is band \& loop space maintainer.3,4 Band and loop space J Evolution Med Dent Sci / eISSN - 2278-4802, pISSN - 2278-4748 / Vol. 10 / Issue 31 / Aug. 02, 2021 maintainers are usually indicated for unilateral single tooth loss. They are easy to fabricate, requires less chairside time, cost effective and also adapt to the changing dentition. ${ }^{3}$ Multiple modifications of this appliance also improves its range of use. Even though it is considered as one of the most effective and efficient appliances, it has multiple disadvantages such as need for second appointment to place the appliance, require more laboratory time, failure of appliance due to loss of cement or due to breakage of the wire component, leads to decalcification under the bands and accumulation of plaque. This leads to caries formation at the margins of the band and periodontal problems. ${ }^{3,9}$ The fabrication of these space maintainers requires a clinician and a laboratory technician which makes it more labour intensive, time consuming and more expensive. ${ }^{10}$

To overcome these disadvantages, newer variations such as direct bonded space maintainer and fiber reinforced composite space maintainers have been developed. These space maintainers contain composite resin reinforced with polyethylene fibers or glass fibers. Impregnation of a brittle material such as composite with fiber improves its mechanical properties such as strength, stiffness, and fracture toughness. ${ }^{5}$ Fiber also provides greater flexural strength than stainless steel, titanium, and zirconia. ${ }^{11}$ Apart from the obvious improvement in mechanical properties, these retainers show enhanced aesthetics, as they are less bulky, occupy less space and give a natural feel. These retainers do not require impressions, nor do they require laboratory time. It is easier to apply and can be finished in a single visit with less chairside time. ${ }^{12}$ It also eliminates the need for annual inspection unlike the other types of space maintainers. ${ }^{6}$ There is not much literature regarding the use of fiber reinforced composite as a space maintenance appliance.

Therefore, the 7 articles included in this review were studied to determine if these fiber reinforced composites are as effective as the conventional band and loop maintainers. Table 3 shows the data that was collected and analysed.

Miller et al. ${ }^{1}$ did a comparative study wherein conventional band and loop, glass fiber reinforced composite and glass impregnated fiber reinforced composite space maintainers were compared. In this study, 45 space maintainers were placed. The patients were divided into 3 groups, group I (15 patients) received conventional band and loop space maintainer, group II (15 patients) received glass FRCR (everStick C and B, GC Europe) and group III (15 patients) received impregnated glass fibers (interlig, Angelus Londrina Brasil). Periodic follow up was done at $3^{\text {rd }}, 6^{\text {th }}, 12^{\text {th }}$ month. Patient acceptance was measured using Wong baker scale and the space maintenance was assessed using the Swaine and Wright method. The final statistical analysis was done using the chi square test and Kruskal-Wallis test. The failure of the group I was mainly because of cement loss or the fracture of the loop, group II showed failure due to debonding at enamelcomposite interface while group III showed failure due to debonding at enamel-composite, composite-fiber interface and also due to fracture of the fiber framework. This study concluded that the conventional band and loop had higher success rate during all the follow up appointments, but this was not significantly different from that of the FRC. Also, FRC showed better patient acceptability, and was more time and cost effective.

Tunc et al. ${ }^{3}$ compared the survival of conventional band and loop, direct bonded and fiber reinforced composite space 
maintainer. In this study, the sample group included 30 patients who were divided into 3 groups. Group 1 (10 patients) received band \& loop space maintainer, group 2 (10 patients) received direct bonded space maintainer and group 3 (10 patients) received the fiber reinforced space maintainer. Follow up was done at $3^{\text {rd }}, 6^{\text {th }}, 9^{\text {th }}$ and $12^{\text {th }}$ month. The survival rates were assessed using the Kaplan-Meier method. The data obtained from this study showed that the main cause of failure in group 1 was due to cement loss, while in group 2 it was due to broken wire ends on the abutment and in group 3, it was due to debonding at enamel-composite interface. This study hence concluded that conventional band and loop had better survival and success rate compared to the other 2 variants. Fiber reinforced composite has the least survival and success rate. This study also showed that the survival and success rate do not depend on the patient's age, sex, and jaw side.

Rani et al. ${ }^{4}$ did a comparative study in 30 patients wherein fiber reinforced composite was placed in one quadrant and band \& loop space maintainer was placed in another quadrant in the same patient. The band and loop space maintainer was fabricated according to technique given by Graber and Finn and the FRCR loop was constructed using the Ribbond system. Follow up was done at $1^{\text {st }}, 3^{\text {rd }}, 6^{\text {th }}$ and $9^{\text {th }}$ month. The statistical analysis was done with the analysis of variance (ANOVA) test and post-hoc Tukey test. The main cause of failures in FRCR was due to either debonding at the tooth-composite interface or fiber-composite interface, while the band and loop showed failure mostly due to cement loss. Ultimately this study concluded that the fiber reinforced composite showed higher overall success rate and retention rate compared to the band \& loop space maintainer.

Saravana Kumar et al. ${ }^{11}$ did a clinical follow up study by placing fiber reinforced composite space maintainer in 30 children. The FRCR was fabricated using Ribbond. Periodic follow up was done at $1^{\text {st }}, 6^{\text {th }}, 12^{\text {th }}$ and $18^{\text {th }}$ month. The data was analysed using Fisher exact test and Kaplan-Meiner survival analysis. The failure of the space maintainers was either due to debonding between the tooth and the appliance or debonding between the Ribbond ribbons. This study concluded that the FRC can be considered as a successful space maintainer only for short period of time and also that the success of the appliance depends on operator experience, isolation and choosing of favourable patient groups.

Potgeiter et al. ${ }^{13}$ did an in vivo study comparing the fiber reinforced composite and band \& loop space maintainer. In this study, the patients were divided into 2 sample groups where 10 patients received the FRCR space maintainers and 10 patients received band \& loop space maintainers. The study was conducted for 6 months with a follow up every month. The data collected was analysed using two sample t-test and the non-parametric Wilcoxon rank sum test. The main cause for the failure of the FRCR space maintainer was due to debonding at enamel-composite and composite-fiber interface and fracture of the fiber loop, while the band \& loop failed due to bending of the loop and impingement on soft tissues. The overall failure rates of both appliances didn't show a significant difference and the study concluded by saying that the effectiveness of the fiber reinforced composite is limited by its bond strength and hence requires further studies to improve its characteristics.

Garg et al. ${ }^{14}$ did a comparative study in 30 patients wherein the fiber reinforced composite was compared to the conventional band \& loop. The patients were divided into 2 groups, group I (placed in one quadrant) received fiber reinforced composite space maintainer while group II (placed in another quadrant of the same patient) received conventional band and loop space maintainer. Follow up was done at $1^{\text {st }}, 3^{\text {rd }}$ and $6^{\text {th }}$ month. The patient acceptance was assessed using the Wong Baker scale and the data collected was analysed using chi square test and Mann-Whitney U test. This study concluded that the success rate was higher in fiber reinforced composite and also fiber reinforced composite had better patient acceptance, was less time consuming and was superior in clinical efficacy compared to the conventional band and loop. The author concluded that the FRC was a worthy alternative to the conventional band and loop.

Yassa et al. ${ }^{15}$ did an in vitro and in vivo study to test the efficacy of FRC. In the in vitro study, 15 samples were studied, they were divided into 3 groups, group I was composite resin without fibers (5 samples), group II was FRC reinforced with 1 fiber bundle (5 samples) and group III consisted FRC reinforced with 2 fiber bundles (5 samples). The mean structural strength of these samples was done using 3-point bend test. In the in-vivo study, 15 patients received space maintainers, FRC space maintainer in one quadrant and band and loop space maintainer in another quadrant of the same patient. Periodic follow up was done at $11^{\text {st }}, 3^{\text {rd }}, 6^{\text {th }}$ and $12^{\text {th }}$ month.

The patient and parent satisfaction for each of the space maintainer was assessed using the 5-point Likert scale and the gingival health was assessed using the Loe and Silness Index. In the in-vitro study, the mean structural strength of FRC with 2 fiber bundles was the highest compared to the other 2 groups and the in vivo study showed that the FRC has better success rate than the conventional band and loop. The main cause of failure of band \& loop space maintainer in the in-vivo study was due to cement loss and for the FRC, the main cause of failure was due to delamination at fiber-composite interface. The author concluded by stating that FRC is a superior alternative to conventional band \& loop and the author suggested the use of FRC reinforced with 2 fiber bundles for better properties.

\section{CONCLUSIONS}

In conclusion, despite being one of the gold standard appliances for space maintenance, the conventional band and loop space maintainers have multiple disadvantages. The major disadvantage included failure of the appliance due to cement loss and bending of the wire. The studies also reported that patient acceptance for conventional band and loop was lower and the time taken for the placement was higher. On the other hand, out of the 7 articles included in this study, 6 of the articles concluded that the FRC space maintainers are as effective as the conventional band and loop. FRC space maintainers proved to be time effective, more aesthetic, has better patient acceptance and is easier to fabricate. It also showed better retention in the oral cavity. But the survival rate and the efficiency of the space maintainers highly depends on the operator skills, proper isolation of field and appropriate patient selection.

Hence, fiber reinforced composite space maintainers can be used as a more aesthetic and effective alternative to the 
conventional band and loop space maintainers if proper technique and protocol is followed.

Financial or other competing interests: None.

Disclosure forms provided by the authors are available with the full text of this article at jemds.com.

\section{REFERENCES}

[1] Mittal S, Sharma A, Sharma AK, et al. Banded versus single-sided bonded space maintainers: a comparative study. Indian Journal of Dental Sciences 2018;10(1):2936.

[2] Goenka P, Sarawgi A, Marwah N, et al. Simple fixed functional space maintainer. Int J Clin Pediatr Dent 2014;7(3):225-8.

[3] Tunc ES, Bayrak S, Tuloglu N, et al. Evaluation of survival of 3 different fixed space maintainers. Pediatr Dent 2012;34(4):e97-102.

[4] Rani R, Chachra S, Dhindsa A, et al. Clinical success of fixed space maintainers: conventional band and loop versus fiber-reinforced composite loop space maintainer. $\mathrm{N}$ Niger J Clin Res 2020;9(15):1-6.

[5] Yeluri R, Munshi AK. Fiber reinforced composite loop space maintainer: an alternative to the conventional band and loop. Contemp Clin Dent 2012;3(Suppl 1):S26-8.

[6] Ramakrishnan M, Dhanalakshmi R, Subramanian EMG. Survival rate of different fixed posterior space maintainers used in paediatric dentistry-a systematic review. Saudi Dent J 2019;31(2):165-72.
[7] Setia V, Pandit IK, Srivastava N, et al. Space maintainers in dentistry: past to present. J Clin Diagn Res 2013;7(10):2402-5.

[8] Subramaniam P, Babu G, Sunny R. Glass fiber-reinforced composite resin as a space maintainer: a clinical study. J Indian Soc Pedod Prev Dent 2008;26(Suppl 3):S98-103.

[9] Setia V, Pandit IK, Srivastava N, et al. Banded vs bonded space maintainers: finding better way out. Int J Clin Pediatr Dent 2014;7(2):97-104.

[10] Kulkarni G, Lau D, Hafezi S. Development and testing of fiber-reinforced composite space maintainers. J Dent Child (Chic) 2009;76(3):204-8.

[11] Saravanakumar M, Siddaramayya J, Sajjanar AB, et al. Fiber technology in space maintainer: a clinical follow-up study. J Contemp Dent Pract 013;14(6):1070-5.

[12] El-Patal MA, Asiry MA, AlShahrani I, et al. The effect of fiber-reinforced composite versus band and loop space maintainers on oral lactobacillus acidophilus and streptococcus mutans levels in saliva. J Indian Soc Pedod Prev Dent 2018;36(3):301-7.

[13] Potgieter N, Brandt PD, Mohamed N. Clinical evaluation of the loop-design fiber-reinforced composite and the bandand-loop space maintainers. S Afr Dent J 2018;73(7).

[14] Garg A, Samadi F, Jaiswal JN, et al. Metal to resin: a comparative evaluation of conventional band and loop space maintainer with the fiber reinforced composite resin space maintainer in children. J Indian Soc Pedod Prev Dent 2014;32(2):111-6.

[15] Kamal YM, Mohammed KN. Evaluation of posterior fixed functional space maintainers made of fiber reinforced composite. Oral Health and Dental Management $2017 ; 16(2)$. 